RESEARCH

\section{SERIES}

NUMBER 110

November 2020

\title{
EFFECTIVE TAX RATES IN IRELAND
}

\section{ILIAS KOSTARAKOS AND PETROS VARTHALITIS}

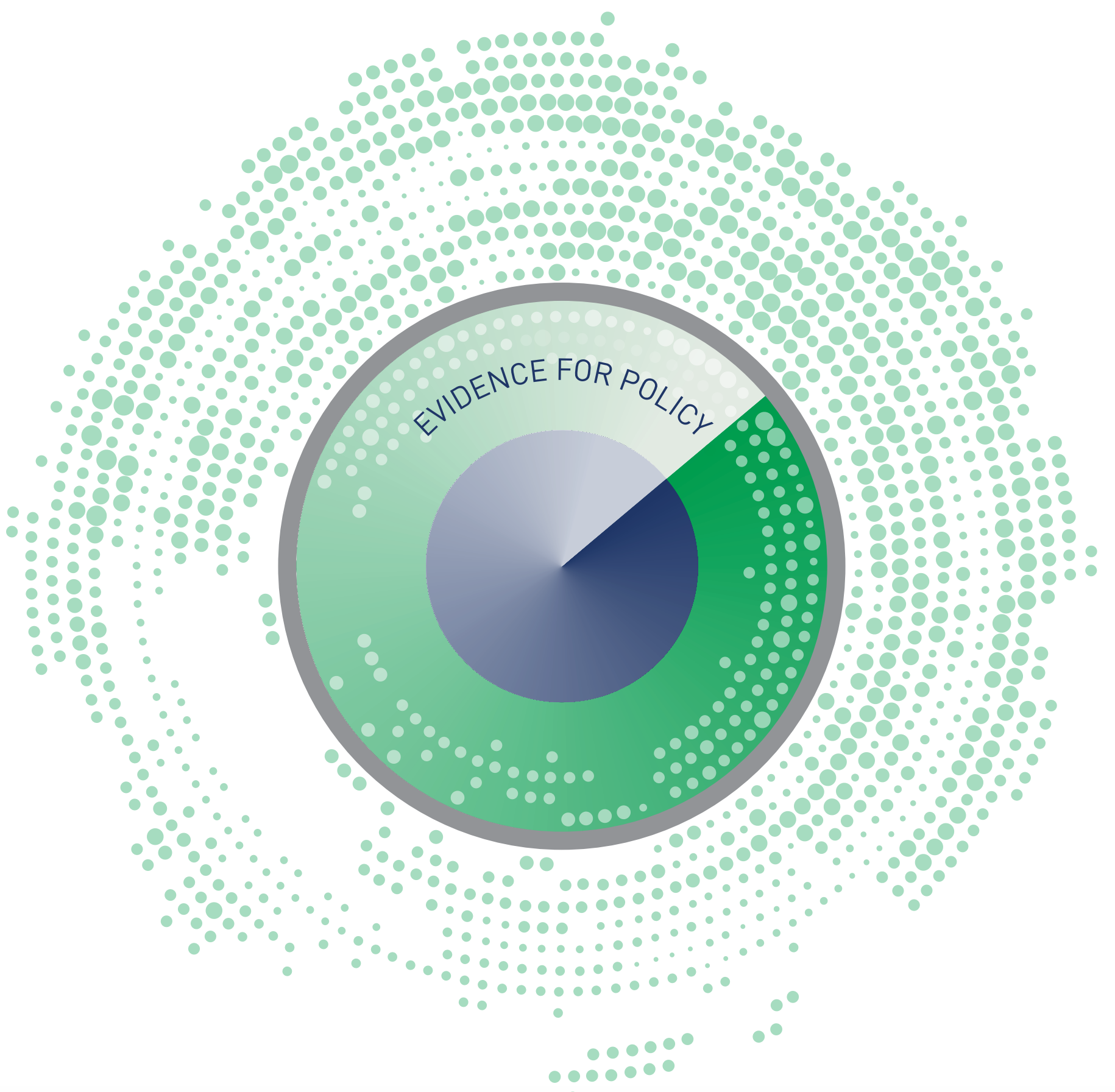




\section{Effective tax rates in Ireland}

Ilias Kostarakos

Petros Varthalitis

September 2020

\section{RESEARCH SERIES \\ NUMBER 110}

Available to download from www.esri.ie

() The Economic and Social Research Institute

Whitaker Square, Sir John Rogerson's Quay, Dublin 2

ISBN 978-0-7070-0543-0

DOI https://doi.org/10.26504/rs110

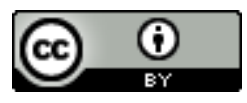

This Open Access work is licensed under a Creative Commons Attribution 4.0 International License (https: //creativecommons.org/licenses/by/4.0/), which permits unrestricted use, distribution, and reproduction in any medium, provided the original work is properly credited. 


\section{ABOUT THE ESRI}

The mission of the Economic and Social Research Institute is to advance evidence-based policymaking that supports economic sustainability and social progress in Ireland. ESRI researchers apply the highest standards of academic excellence to challenges facing policymakers, focusing on 12 areas of critical importance to 21 st century Ireland.

The Institute was founded in 1960 by a group of senior civil servants led by Dr T. K. Whitaker, who identified the need for independent and in-depth research analysis to provide a robust evidence base for policymaking in Ireland.

Since then, the Institute has remained committed to independent research and its work is free of any expressed ideology or political position. The Institute publishes all research reaching the appropriate academic standard, irrespective of its findings or who funds the research.

The quality of its research output is guaranteed by a rigorous peer review process. ESRI researchers are experts in their fields and are committed to producing work that meets the highest academic standards and practices.

The work of the Institute is disseminated widely in books, journal articles and reports. ESRI publications are available to download, free of charge, from its website. Additionally, ESRI staff communicate research findings at regular conferences and seminars.

The ESRI is a company limited by guarantee, answerable to its members and governed by a Council, comprising 14 members who represent a cross-section of ESRI members from academia, civil services, state agencies, businesses and civil society. The Institute receives an annual grant-in-aid from the Department of Public Expenditure and Reform to support the scientific and public interest elements of the Institute's activities; the grant accounted for an average of 30 per cent of the Institute's income over the lifetime of the last Research Strategy. The remaining funding comes from research programmes supported by government departments and agencies, public bodies and competitive research programmes.

Further information is available at www.esri.ie 


\section{THE AUTHORS}

Ilias Kostarakos is a Post-Doctoral Research Fellow and Petros Varthalitis is a Research Officer at the Economic and Social Research Institute (ESRI).

\section{ACKNOWLEDGEMENTS}

This research is part of the joint research programme "Macroeconomy, Taxation and Banking" between the ESRI, the Department of Finance and Revenue Commissioners and we are grateful for helpful comments of the programme steering committee. We would like to thank two anonymous referees, David Hughes, Martina Lawless, Sean Lyons, Matthew McGann, Kieran McQuinn, Diarmaid Smyth, Oisin Tarrant and participants at the Quarterly Macro Meet Up seminar series at the ESRI for useful comments. Any errors and the views expressed in this paper are our own.

This report has been accepted for publication by the Institute, which does not itself take institutional policy positions. The report has been peer-reviewed prior to publication. The authors are solely responsible for the content and the views expressed. 


\section{Table of Contents}

1 Executive Summary 1

2 Introduction $\quad 2$

3 Data and methodology $\quad 4$

4 Effective tax rates in Ireland $\quad 4$

4.1 Main effective tax rates over time . . . . . . . . . . . . . . . 5

4.2 Other effective tax rates over time $\ldots \ldots \ldots \ldots \ldots$

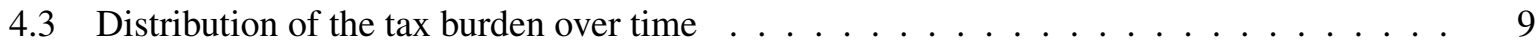

4.4 Comparison of Ireland with different groups of EU countries . . . . . . . . . . . 9

5 Macroeconomic performance and effective tax rates 14

6 Conclusions $\quad 17$

$\begin{array}{ll}\text { A Appendix } & \mathbf{2 0}\end{array}$

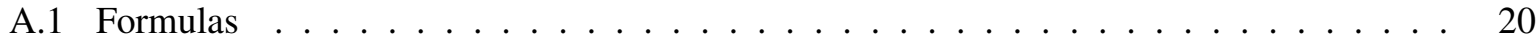

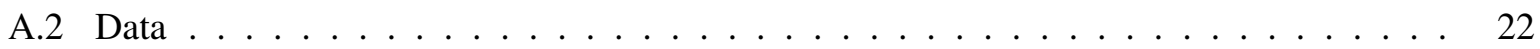




\section{Executive Summary}

This article provides estimates of the effective tax rates in Ireland for the 1995-2017 period. We use these aggregate tax indicators to compare the developments in the Irish tax policy mix with the rest of the European Union countries and investigate any potential relation with Ireland's macroeconomic performance. Our findings show that distortionary taxes, e.g. on factors of production, are significantly lower while less distortionary taxes, e.g. on consumption, are higher in Ireland than most European countries. Thus, the distribution of tax burden falls relatively more on consumption and to a lesser extent on labour than capital; while in the EU average the norm is the opposite. The descriptive analysis indicates that this shift in the Irish tax policy mix is correlated with the country's strong economic performance. 


\section{Introduction}

This article provides estimates of aggregate tax indicators, the so-called effective tax rates, ${ }^{1}$ for the Irish economy over the 1995-2017 period. In particular, we follow the methodology developed in Mendoza et al. (1994) to compute the main tax indicators for Ireland, i.e. the effective tax rates on the factors of production (labour and capital), on corporate income and on consumption. ${ }^{2}$ We also compute a set of additional effective tax rates (that are not included in European Commission reports), namely the combined effective tax rate on consumption and labour and the tax rates related to the actual security contributions paid by employers and employees. These various measures of aggregate tax rates allow us to compare Ireland's tax policy mix with the EU average at the aggregate level. Full technical details of the methodology are provided in Kostarakos and Varthalitis (2020). Effective tax rates are aggregate, ex post, tax indicators that can account for the net effect of the existing rules of national tax systems regarding exemptions, deductions and credits and, thus, are ideally suited for international comparisons. One drawback of this approach is that, unlike marginal tax rates, it does not take into account information on statutory tax rates and the income distribution per tax bracket. However, as mentioned in Mendoza et al. (1994), it is not clear whether the marginal tax rates are equivalent to the aggregate tax rates that affect the evolution of the main macroeconomic variables and economic growth, which is the focus of this paper. ${ }^{3}$ There are several papers that compute effective tax rates for EU and OECD countries e.g. Carey and Tchilinguirian (2000), Martinez-Mongay (2000), Carey and Rabesona (2002), Volkerink et al. (2002) and McDaniel (2007) while the European Commission in an annual series of reports compute the effective tax rates for the European Union countries (see e.g. European Commission (2007-2019)). We are not aware of other country specific studies with the exception of Papageorgiou et al. (2012) which compare effective tax rates in Greece with the Eurozone average for 2000-2009. ${ }^{4}$ For the case of Ireland there are two reports that limit their attention to the estimation of the effective corporate tax. Coffey and Levey (2014) assess eight different methodologies to estimate the corporate effective tax rate in Ireland, while Coffey (2017) updates these estimates using data covering the period 2000-2015. Our estimates for the Irish effective corporate tax rate are very close to the ones in Coffey and Levey (2014) and Coffey (2017), when they use the national aggregates approach (any differences are due to subsequent revisions of the data by Eurostat). Coffey and Levey (2014) and Coffey (2017) also compute

1 Also known as implicit tax rates according to the European Commission, or tax ratios (see Volkerink et al. (2002) and Arachi et al. (2015)).

2 The European Commission publishes an annual report - see European Commission (2007-2019) - with estimates of ETRs on consumption and labour, capital and corporate income for all the European Union countries. This report also presents estimates for social security contributions ETRs, but for a single year - 2017 - only.

3 As the focus of the paper is on assessing the relationship between the Irish tax policy mix and macroeconomic developments, we abstract from any analysis related to the distributional impact of relative effective taxation. We note here that the relevant literature based on these indicators has not examined such issues.

4 There are numerous papers that have utilised effective tax rate estimates in their analysis, ranging from empirical papers examining the impact of taxation on growth (see, among others, Angelopoulos et al. (2007), Arachi et al. (2015), Mendoza et al. (1997) and Gemmell et al. (2014)), on labour market outcomes (Berger and Everaert (2010), Daveri and Tabellini (2000), Fiorito and Padrini (2001)) as well as inputs for DSGE models (e.g. Uhlig and Trabandt (2011)). 
corporate income effective tax rates using the Revenue Commissioners' "Income Tax and Corporation Tax Distribution Statistics", which provide a more detailed description of the tax system compared to the National Accounts. The ETR estimates are, in this case, higher compared to the ones based on the National Accounts data. This reflects the fact that Net Operating Surplus does not provide a perfect measure of the tax base, since it does not fully capture the tax implications of activities of firms. This is related to the limited extent that National Accounts data align with amortisation for tax purposes, the role of losses, which are likely to have been significant in the wake of the financial crisis, and the treatment of interest payments to cover financing costs. However, we report that the trend in the data over time is similar to that found in Coffey and Levey (2014) and Coffey (2017). Thus, this is the first paper that computes the full set of the effective tax rates for Ireland in a unified framework; it also utilises these ETRs to compare the Irish tax mix with the EU average and various country groupings and draw some conclusions about their effect on Ireland's macroeconomic performance. The Irish economy has some distinct structural characteristics that one should take into account when trying to interpret the path of tax indicators; these include, among others, its remarkable degree of trade openness, the export-oriented tradable sector and the significant effect of FDI on the domestic economy. ${ }^{5}$ Our main results are the following. First, taxes that distort economic incentives - that is labour, capital and corporate income taxes - and/or increase the non-wage cost, are significantly lower in Ireland compared to the EU average and to most individual European countries. Second, relatively less distorting taxes, such as taxes on consumption, are significantly higher in Ireland; this is in spite of the fact that, since 2008 the Irish consumption tax indicator converged to the EU average and they now follow a similar path. Third, as expected from the previous results, the distribution of tax burden among consumption, capital and labour differs in Ireland compared to the EU average. In Ireland, a shift away from capital taxation towards (mainly) consumption and labour taxes took place over the period under examination. In contrast, the EU averages indicate that the tax burden falls relatively more on the side of labour and capital rather than consumption. Comparing Ireland's macroeconomic performance with the rest of the EU countries, our results indicate that the Irish tax policy mix could be one of the key factors that contribute to its strong economic performance. For example, GDP growth, business investment and hours worked seem to be negatively correlated with distorting taxes such as taxes on labour and capital, for which the burden is relatively smaller in the case of Ireland.

The remainder of this paper is organised as follows. Section 3 reports our data and briefly describes the methodology, Section 4 presents results on the tax indicators and, finally, Section 5 discusses the relation between macroeconomic performance and the tax policy mix. An Appendix lists our dataset and presents the formulas for each effective tax rate.

5 It should also be hightlighted that during the time period from 1995 to 2017 the Irish economy was exposed to various and different economic conditions, such as the Celtic Tiger era, the Property Bubble, the 2008 crisis and subsequent recovery etc. There are numerous papers that study the various historical events of this period, see e.g. McQuinn and Varthalitis (2020) and the references therein. As already stated, our analysis is largely descriptive thus abstracting from any normative aspects of fiscal policy. 


\section{Data and methodology}

Our sample consists of annual data for Ireland and European Union countries ${ }^{6}$ over the period 1995-2017. Data are extracted from the Eurostat database. In particular, we employ data from the Annual National Accounts Series (nama_10_gdp), the Non-Financial Annual Sector Accounts (nasa_10_nf_tr) and the Tax Aggregates of Annual Government Finance Statistics (gov_10a_taxag). Table A1 in the Appendix contains the variables used along with their ESA 2010 codes. In order to compute the effective tax rates (ETRs) we mainly follow the methodology developed in Mendoza et al. (1994), incorporating a number of revisions introduced in Carey and Rabesona (2002). In general, effective tax rates are defined as the ratio of tax revenues divided by the associated tax base. This ratio is computed as follows. First, the numerator, which measures the difference between post- and pre-tax valuations of consumption and labour and capital income, is approximated by the realised tax revenues for each tax heading. Second, the denominator, which is a measure of consumption and the income derived from labour and capital at pre-tax valuations and thus corresponds to the tax base, is approximated using the associated aggregate macroeconomic variables. Thus, the formula for any effective tax rate, $\tau$, is:

$$
\tau=\frac{\text { tax revenues }}{\text { tax base }}
$$

To save space we present specific formulas for each ETR in section A.1 of the Appendix while a detailed analysis of our methodology can be found in the companion paper - see Kostarakos and Varthalitis (2020). In what follows, we first present results on Ireland's ETRs and then proceed with conducting a comparison of Ireland with a number of different country groups.

\section{Effective tax rates in Ireland}

Table 1 presents the main effective tax rates for Ireland and the EU average over the 1995-2017 period. In what follows the EU average is computed as the simple arithmetic mean of the 27 countries of our sample. Table 1 shows taxes on the various sources of income, i.e. labour, capital and corporate income, ${ }^{7}$ and on consumption expenditures. For illustrative purposes, we compute the average of ETR time series over various time sub-periods. These taxes that have been found to be relatively more distorting in standard textbook economic theory and most of the empirical literature, ${ }^{8}$ such as taxes levied on the factors of

6 In particular, the sample includes Austria, Belgium, Bulgaria, Cyprus, Czech Republic, Denmark, Estonia, Finland, France, Germany, Greece, Ireland, Italy, Latvia, Lithuania, Luxembourg, Hungary, Malta, Netherlands, Poland, Portugal, Romania, Slovakia, Slovenia, Spain, Sweden and United Kingdom. Croatia is excluded due to insufficient Sector Accounts data.

7 In this paper we focus on the non-financial corporations only. The main reason is their relative importance, for the Irish economy, in terms of the composition of corporate tax receipts. In particular, non-financial corporations tax receipts account - on average - for 77 per cent of the overall corporate tax receipts in Ireland. In addition, this choice makes our results directly comparable to those in Coffey and Levey (2014) and Coffey (2017).

8 For example, Kneller et al. (1999) find a significant negative impact of distortionary taxes, while Lee and Gordon (2005) find a negative impact of corporate taxes on growth. Mendoza et al. (1997) find a negative impact of both labour and capital income taxes on aggregate investment. 
production, are consistently lower in Ireland than the EU average. On the other hand, the less distorting consumption tax is higher in Ireland.

In particular, the ETRs on labour and capital income are lower in Ireland by 8 p.p. and 18 p.p. between 1995 and 2017 on average. Similarly, the ETR on coprorate income is lower by 7 p.p., though as flagged in Section 2, the use of Net Operating Surplus to approximate the tax base may understate the ETR estimate. ${ }^{9}$ At the same time, Ireland's consumption ETR is on average almost 4 p.p. higher than the EU average. Thus, Ireland's tax policy mix seems to incentivise businesses and labour relatively more when compared to the EU average. Relatively low distortionary taxes could contribute to the strong economic performance by enhancing the prospects of sustainable growth and creating a business environment that attracts FDI and high skilled workers.

Table 1: Comparison of Irish and EU-average ETRs

\begin{tabular}{c|cc|cc|cc|cc|}
\hline & \multicolumn{2}{|c|}{ Labour } & \multicolumn{2}{c|}{ Capital } & \multicolumn{2}{c|}{ Consumption } & \multicolumn{2}{c|}{ Corporate } \\
\hline & Ireland & EU & Ireland & EU & Ireland & EU & Ireland & EU \\
\hline $1995-2017$ & 36.01 & 44.3 & 19.7 & 36.8 & 20.1 & 16.6 & 10.4 & 17.8 \\
$1995-2001$ & 35.8 & 42.8 & 21.8 & 36.4 & 21.6 & 17.1 & 10.9 & 17.9 \\
$2001-2007$ & 34.8 & 43.7 & 21.1 & 36.3 & 20.9 & 16.7 & 12.4 & 18.1 \\
$2008-2011$ & 35.2 & 44.8 & 18.1 & 35.9 & 17.7 & 15.9 & 10.3 & 17.5 \\
$2012-2017$ & 37.8 & 46.1 & 16.9 & 38.5 & 18.9 & 16.8 & 7.7 & 17.8 \\
\hline
\end{tabular}

Source: Authors' calculations.

In the next section we discuss in more detail the time trends of the main Irish tax indicators and compare them with the associated EU averages.

\subsection{Main effective tax rates over time}

Figure 1 depicts the evolution of Ireland's main ETRs and compares it with the associated EU averages.

We start our discussion with some general observations before moving to the analysis of each ETR time series. As illustrated above, more distortionary ETRs are significantly and consistently lower in Ireland than the EU average. The only aggregate tax indicator that is consistently higher in Ireland is the tax on consumption expenditures. However, in the post-crisis period the Irish ETR on consumption largely converged to the EU average, with their difference now being 2 p.p. on average. All the Irish ETRs dropped at the start of the Irish crisis in 2008 mostly due to the large fall in the associated tax revenues. Following this drop, the Irish labour and consumption taxes have recovered and follow the upward trend of the EU average. This can be attributed to the Irish fiscal policy and Irish business cycle. In particular, the labour and consumption tax recovery was partly due to the tax policy changes implemented as part of

9 The Revenue Commissioners estimate a 2018 ETR for foreign-owned MNEs of 11.6 per cent (see Revenue Commissioners (2020)), while country-by-country reporting data published by the OECD reported a figure of 11.4 per cent for 2016 (see OECD Corporate Tax Statistics Database) 


\section{Figure 1: Main effective tax rates Ireland vs EU 1995-2017}
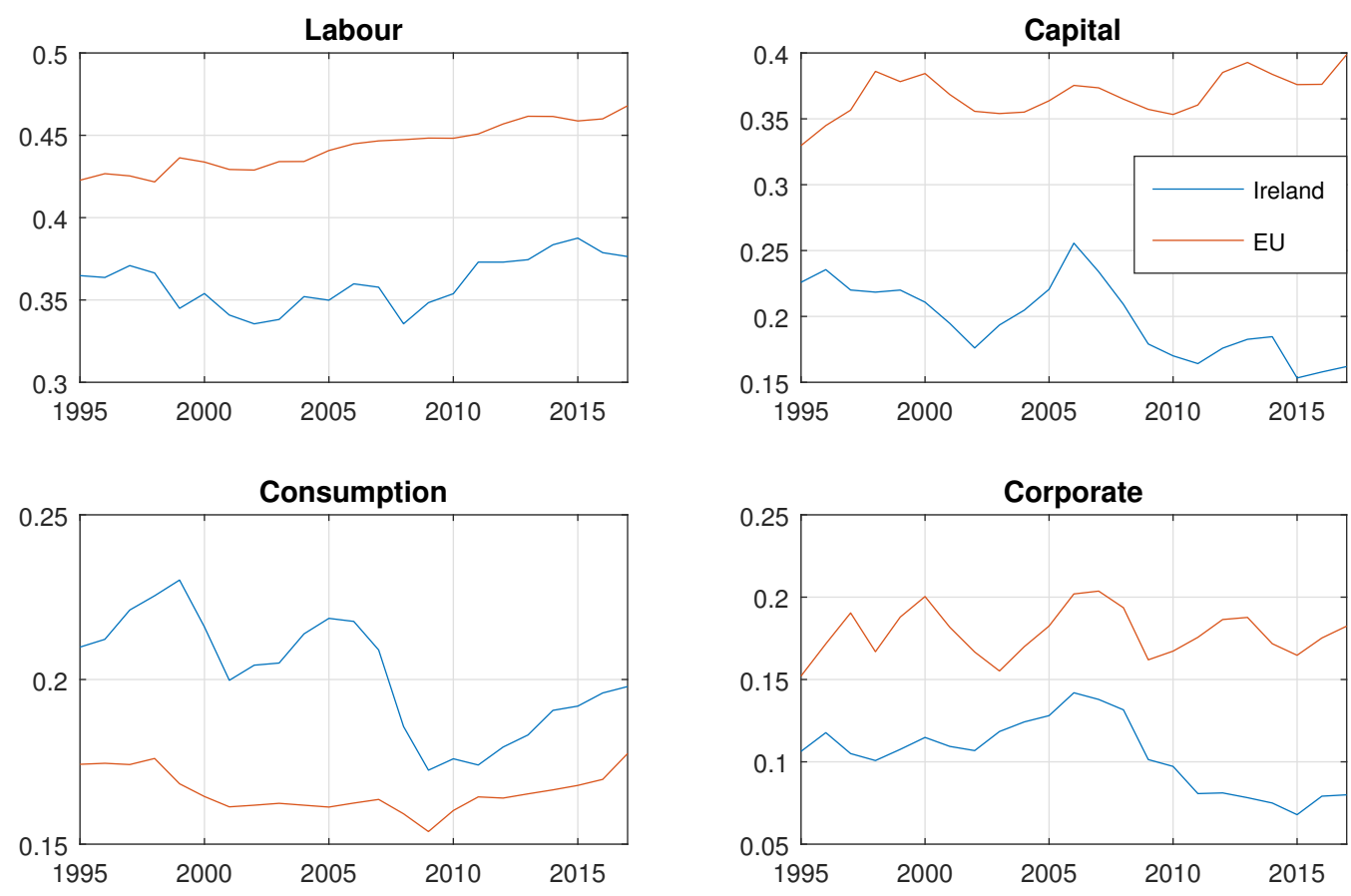

Source: Authors' calculations.

the fiscal consolidation measures launched by the Government during the Irish adjustment programme of 2009-2013, ${ }^{10}$ while, at the same time this trend was further fuelled by the quick economic recovery that led to the rebound of the associated tax revenues.

The upper left panel of Figure 1 presents the evolution of the effective tax rate on labour income. Both the Irish and the EU-average labour tax rates exhibit a mild upward trend since 2002. As mentioned above, the fall of 2008 in Ireland can be attributed to the impact of the Irish crisis, which led to a significant decline of the corresponding tax revenues. From 2008 to 2011, the labour tax indicator saw a noticeable increase that is mostly related to debt consolidation measures launched by the Government as part of the "Troika" programme and the subsequent recovery of the domestic economy. From this period onwards, the labour tax rate follows a mild upward trend similar to the EU average.

The upper right panel in Figure 1 depicts the dynamic time path of the ETR on capital income. We observe an overall downward trend for the Irish capital tax indicator, which from 22 per cent in 1995 fell to 16 per cent by 2017, while the EU average followed a reverse upward trend increasing from 33 per cent in 1995 to almost 40 per cent in 2017. The initial decline of the Irish capital tax in the 1995-2001 period was due to the significant widening of the tax base, whose average annual growth rate (15.3 per cent) exceeds the increase of the tax revenues (12.9 per cent per year). The transitory reverse trend of the

${ }^{10}$ Ireland launched an expenditure based fiscal adjustment programme during 2009-2013, for more details see e.g. McCarthy (2015) and Larch et al. (2016). 
2002-2006 period is related to the strong increase of the capital tax revenues (10 per cent per year) while the corresponding increase in the tax base was only 2 per cent per year. The decline of 2015 is solely attributed to the surge in Gross Operating Surplus, which constitutes a substantial part of the base of the ETR on capital; in particular, in 2015, Gross Operating Surplus increased by 58 per cent (the increase, in levels, was equal to almost $€ 61$ billion).

The ETR on consumption is significantly more volatile in Ireland than the EU average (see the lower left panel). The buoyant period of 2001-2007, followed by the sharp dip in 2007-2008 closely follows the boom and the bust cycle of the domestic demand and the non-tradable sector over the same period. Subsequently, the consumption tax increases due to the consolidation measures. At the same time the recovery of domestic demand post-2009 leads to a recovery in the associated tax revenues. In contrast, the EU average remains stable over the same period. In the post-crisis period the Irish and the EU average tax rates follow a similar upward trend. Also, the relatively more pronounced increase in Ireland signals a possible shift of the tax burden toward this tax category (see the analysis in Section 4.3 below).

Finally, the lower right panel depicts the evolution of the corporate income tax rate (CIT) ${ }^{11}$ CIT ETRs are inherently more volatile than the rest of the tax indicators (see Casey and Hannon (2016)). Ireland is a small open economy characterised by an exceptional degree of openness to trade. In addition, the CIT tax base is concentrated in a small number of foreign-affiliated firms (see Irish Fiscal Advisory Council (2018) and Irish Fiscal Advisory Council (2019)). These structural characteristics make Ireland's CIT ETR more prone to changes in international economic conditions. The average value of the tax rate in Ireland is 10.3 per cent, almost 7 percentage points lower compared to the EU average for the whole period. ${ }^{12}$ For the 1995-2006 period the Irish CIT indicator exhibited an upward trend, reaching its maximum value of 14.2 per cent in 2006, mostly due to the significant increase in CIT revenues. With the onset of the financial crisis, the ETR dropped by 3 p.p between 2008 and 2009, before falling further to 8.1 per cent in 2011, due to the large decrease in revenues (-9.9 per cent per year) while, at the same time, the corresponding tax base remained largely unchanged. The smaller subsequent decline, up to 2014 , is related to the widening of the tax base which outperformed the significant increase of the CIT revenues registered over this period. Finally, after 2015, the decline is solely attributed to the significant increase of the Gross Operating Surplus of non-financial corporations which - as in the case of the capital tax indicator - is part of the tax base. ${ }^{13}$ Similarly with the ETR on capital, the Irish and the EU average CIT trends seem to diverge during the post-crisis period.

11 The effective tax rate on corporate income is based on the income earned by non-financial corporations see Kostarakos and Varthalitis (2020) for more details.

12 Ireland, along with Austria and Germany, has the lowest effective tax rate on corporate income among Eurozone countries.

13 The results for the effective tax rate on corporate income are similar to the ones of the Coffey and Levey (2014) and Coffey (2017) - the small differences are due to the subsequent revisions of the relevant data by Eurostat. 


\subsection{Other effective tax rates over time}

In the previous section we focused on the main ETRs that affect the economic decision-making. However, households' and firms' economic decisions are also influenced by other types of taxes levied by the Government, such as the Social Security Contributions (SSC). These taxes act as a distorting wedge between the wage paid by the employer and the wage received by the employee, and they are the largest contributor to the non-wage cost in each country. Non-wage cost plays a key role in cross-country competitiveness. In Table 2, we compute the ETR on SSC while we further decompose it into the tax burden levied on employers vis-à-vis the one levied on employees. Finally, following Carey and Rabesona (2002), we compute the combined ETR on labour and consumption. This indicator is a measure of the tax burden levied on net labour income. In particular, it measures the tax burden for the choice between supplying labour or enjoying leisure. Its calculation is straightforward:

$$
\tau^{l c}=\tau^{l}+\left(1-\tau^{l}\right) * \tau^{c}
$$

Figure 2: Other effective tax rates Ireland vs EU 1995-2017
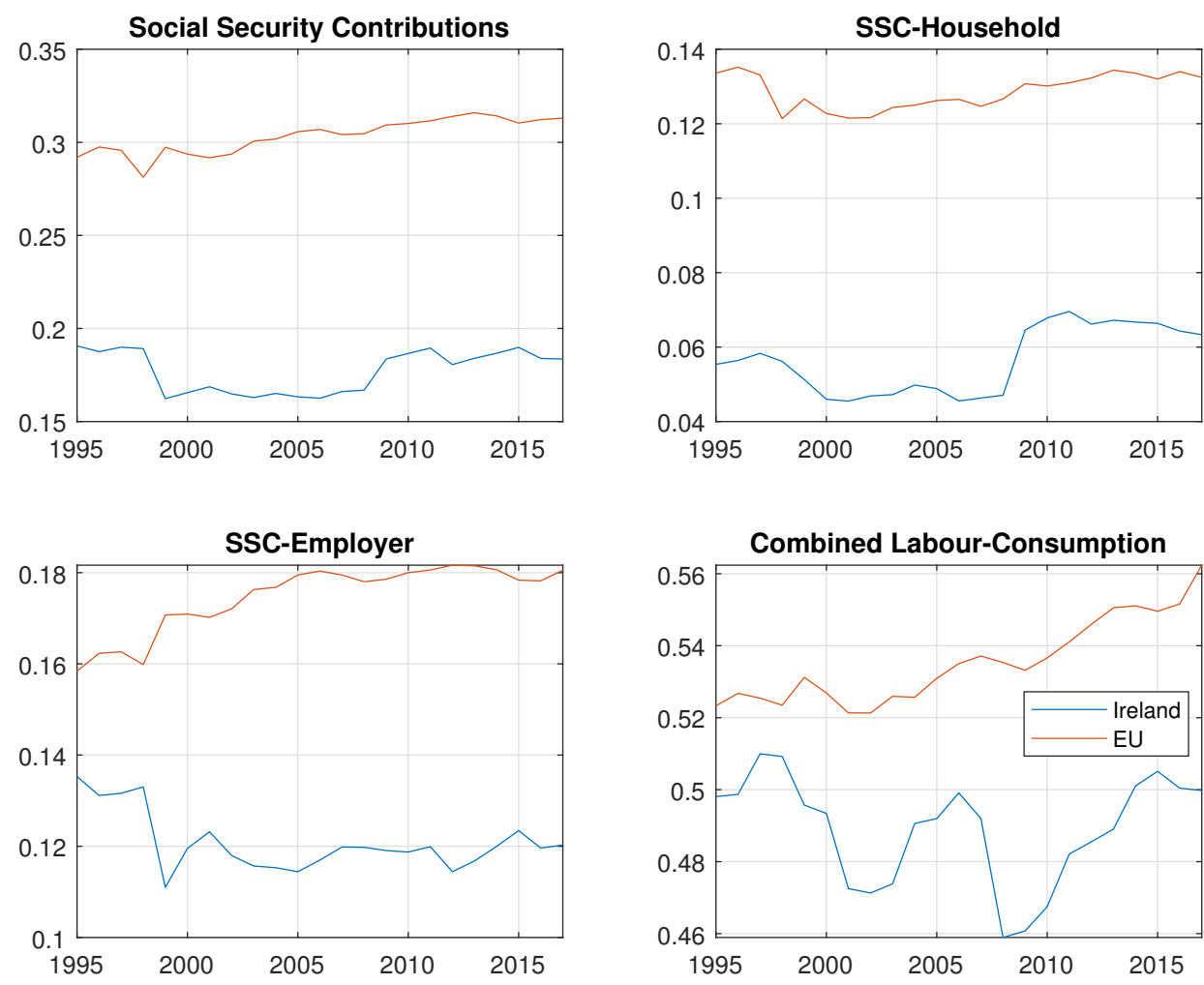

Source: Authors' calculations.

The ETR on SSC is relatively stable in Ireland and the EU, but consistently lower in Ireland than the EU average over time. This tax indicator is one of the factors that reflects the higher labour market 
Table 2: Comparison of Irish and EU-average ETRs (II)

\begin{tabular}{l|ll|ll|ll|ll|}
\hline & \multicolumn{2}{|c|}{ SSC } & \multicolumn{2}{|c|}{ SSC Employer } & \multicolumn{2}{c|}{ SSC Employee } & \multicolumn{2}{c|}{$\boldsymbol{\tau}^{\text {lc }}$} \\
\hline & Ireland & EU & Ireland & EU & Ireland & EU & Ireland & EU \\
\hline $1995-2017$ & 17.7 & 30.3 & 12.07 & 17.4 & 5.63 & 12.9 & 48.9 & 53.5 \\
$1995-2001$ & 17.9 & 29.3 & 12.6 & 16.5 & 5.3 & 12.8 & 49.7 & 52.5 \\
$2001-2007$ & 16.5 & 30.01 & 11.7 & 17.6 & 4.7 & 12.4 & 48.4 & 52.8 \\
$2008-2011$ & 18.2 & 30.9 & 11.9 & 17.9 & 6.2 & 12.9 & 46.7 & 53.6 \\
$2012-2017$ & 18.5 & 31.3 & 11.9 & 18.01 & 6.6 & 13.3 & 49.7 & 55.2 \\
\hline
\end{tabular}

Source: Authors' calculations.

Note: $\tau^{l c}$ denotes the combined labour-consumption effective tax rate.

competitiveness in Ireland with respect to most EU countries. The decomposition of SSC into SSC paid by employers and employees respectively provides us with some further insights on the distribution of the non-wage cost between employees and employers. Figure 2 illustrates that employers in Ireland and the EU bear a larger share of the non-wage cost than employees.

\subsection{Distribution of the tax burden over time}

Relative ETRs allow us to identify potential fiscal policy shifts over time and examine how the relative tax burden is distributed on each economic activity, namely production and consumption, and how it evolves over time. Figure 4.3 shows that in Ireland the economic activities that bear a relatively higher tax burden are consumption and labour while the tax burden on capital steadily falls with a transitory break between 2002 and 2006. This is in contrast with the distribution of the tax burden in the EU. In the EU average, labour and capital bear a higher burden than consumption. Trends in the first and second panel of Figure 4.3 indicate that there is a shift in Ireland's tax policy mix after the eruption of the Irish debt crisis in 2008. The relative tax burden on consumption and labour increases vis-à-vis the tax burden levied on capital. As discussed this can be attributed to two reasons; first to the fiscal consolidation mix chosen that from the side of taxes took place via consumption and labour tax increases, and second, to the widening of the capital tax base that led to a decrease in the ETR on capital.

\subsection{Comparison of Ireland with different groups of EU countries}

In this section we compare Ireland's ETRs with three groups of EU countries. We split the EU countries into groups that exhibit specific common characteristics and have been widely used in the related literature. Figure 4 compares Ireland with countries that were largely affected by the recent European Debt Crisis. This group includes Greece, Portugal, Italy, Spain and Cyprus and is usually referred to as the Periphery. Figure 5 presents the comparison between Ireland and a group of countries - known as the Core - that includes Austria, Belgium, France, Germany and Netherlands. The latter group was less affected by the debt crisis and thus their public finances are considered to be relatively more stable. Finally, Figure 6 
Figure 3: Distribution of the tax burden Ireland vs EU
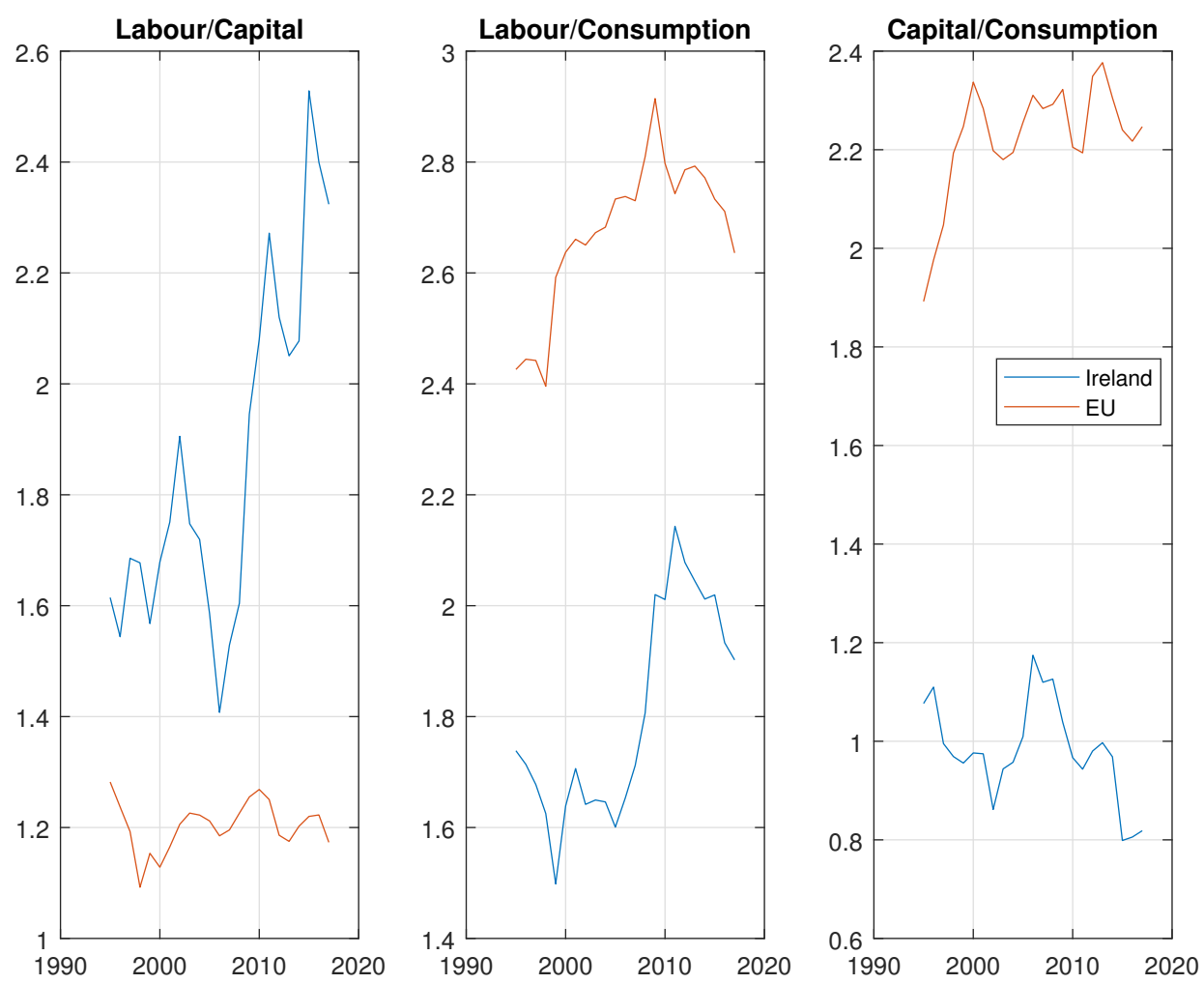

Source: Authors' calculations.

allows for a comparison between Ireland and other small open economies with some similar structural characteristics such as openness to trade and large FDI inflows/outflows.

Figures 4-6 indicate that the main tax trends observed between Ireland and the EU-average are also in place when we compare Ireland with alternative groups of countries. Some results are worth highlighting. First, the difference between Ireland and core countries is more striking and persistent for the more distorting tax indicators, i.e. labour, capital and CIT. In addition, capital and CIT trends seem to diverge even further in the post-crisis period. Thus, core countries levy more distorting taxes on the factors of production. Second, the difference between Ireland and the other periphery countries is relatively smaller in magnitude than the associated Ireland-core difference for labour and capital taxes. However, the Ireland-Periphery difference is larger for consumption and CIT taxes. After the 2008 European Debt Crisis, labour and consumption taxes follow a similar upward trend in Ireland and the Periphery. This can be explained by the similar fiscal consolidation measures that were implemented in the periphery countries. 
Figure 4: Ireland vs Periphery Countries
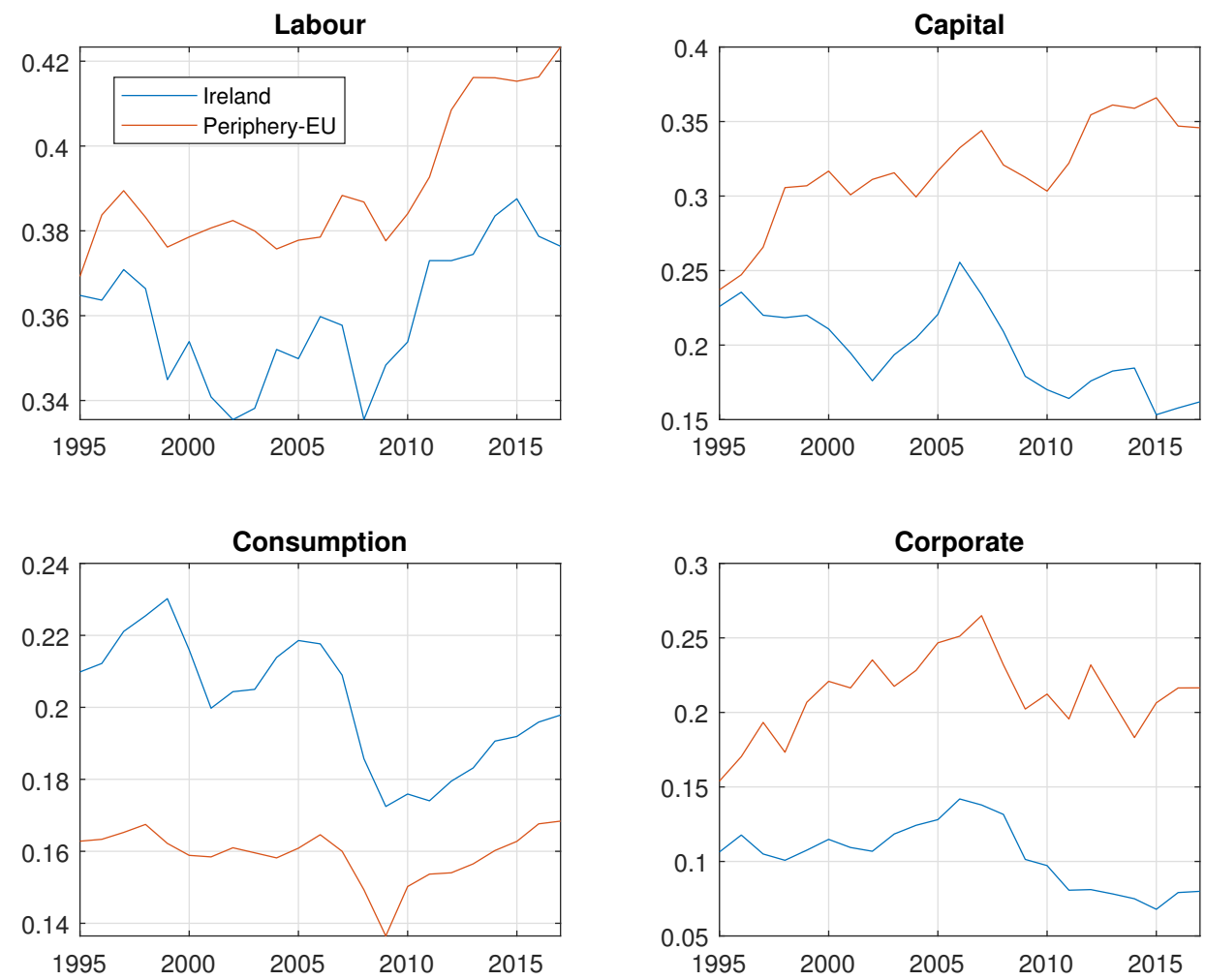

Source: Authors' calculations.

Note: The group of periphery countries includes Greece, Portugal, Italy, Spain and Cyprus. 
Figure 5: Ireland vs Core Countries
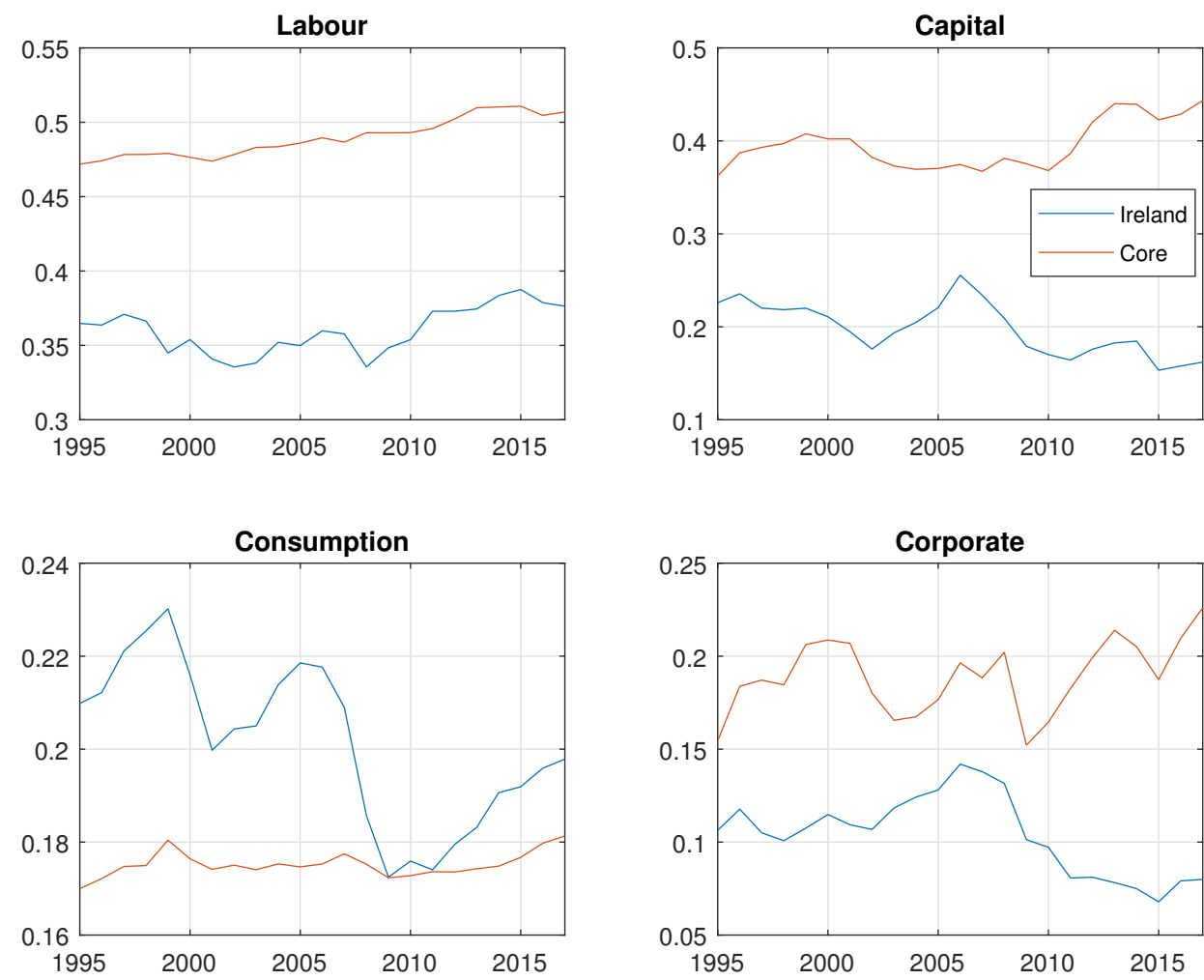

Source: Authors' calculations.

Note: The group of core countries includes Austria, Belgium, France, Germany and Netherlands. 
Figure 6: Ireland vs Small Open Economies
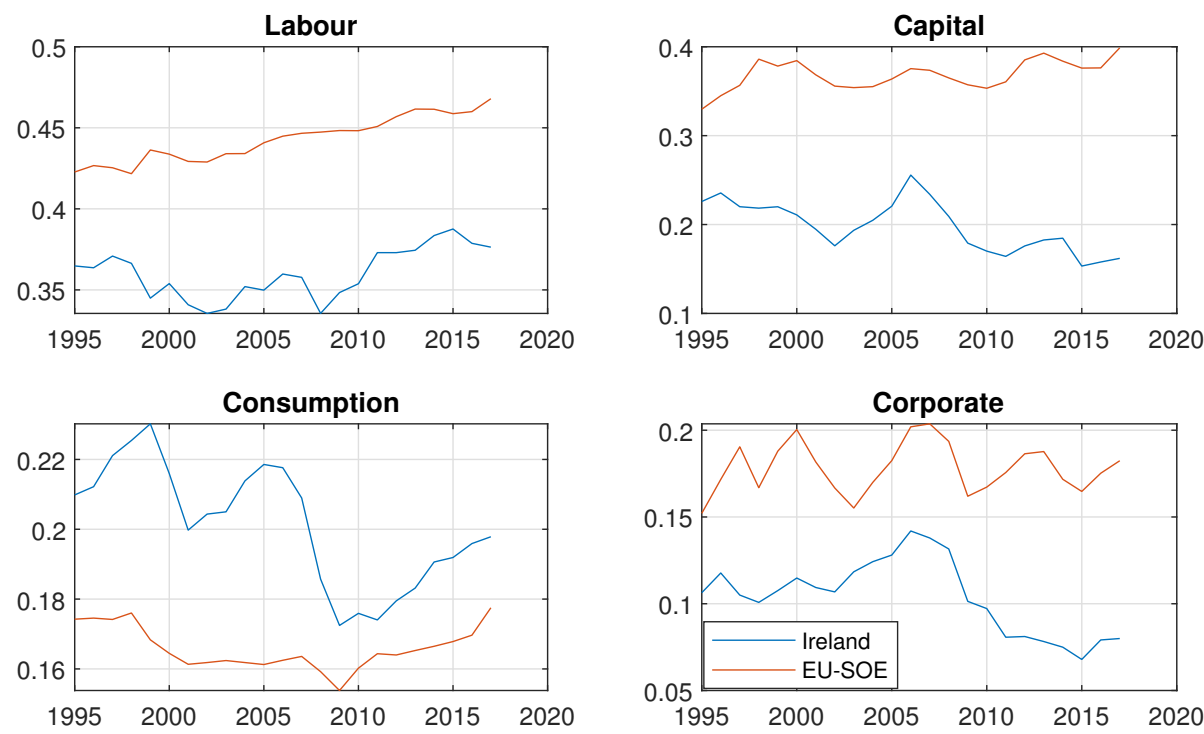

Source: Authors' calculations.

Note: The group of small open economies includes Belgium, Cyprus, Luxembourg and Netherlands. 


\section{Macroeconomic performance and effective tax rates}

In this section we present simple correlations of the tax indicators with key macroeconomic aggregates. These results should be treated with caution as they merely indicate simple correlations rather than causation. Scatter plots in Figure 7 illustrate the correlations between the average ETRs vis-à-vis the average GDP growth rates for the 27 European Union countries over the 1995-2017 period. Visual inspection of these figures indicates a negative relation between real GDP growth and distorting effective tax rates, namely labour, capital and corporation tax.

\section{Figure 7: GDP Growth and ETRs}
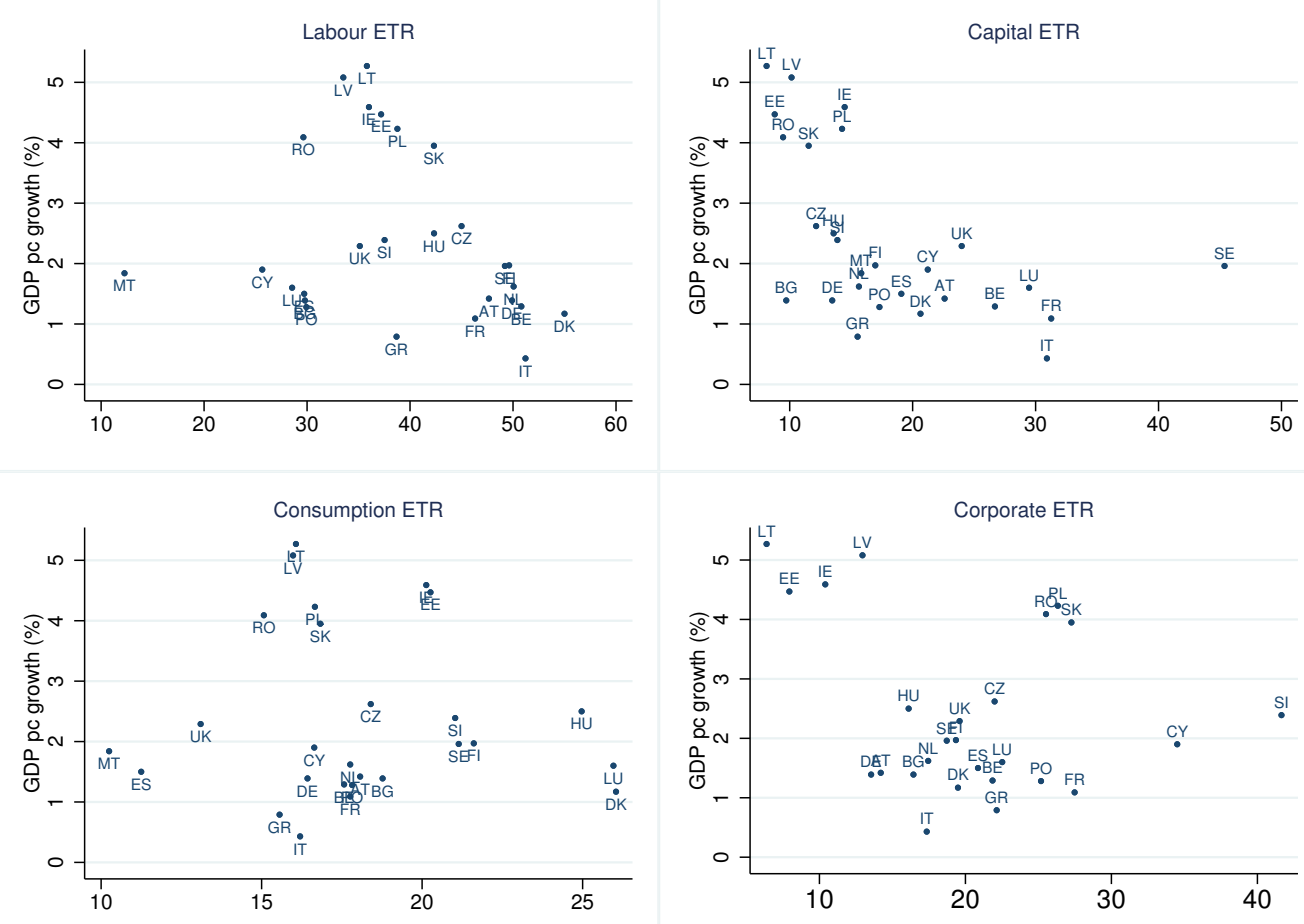

Source: Authors' calculations.

Similarly, scatter plots in Figures 8-9 present relations of hours worked with respect to labour tax and business investment with respect to capital and corporate tax. These figures indicate that hours worked are negatively correlated with labour tax; while capital and corporate tax seem to exhibit a downward sloping relation with business investment. Our descriptive analysis seems to confirm the standard macroeconomic theory findings that relatively more distortive taxes can be harmful for employment and investment and thus for GDP growth. 
Figure 8: Relation between hours worked and labour tax in the EU

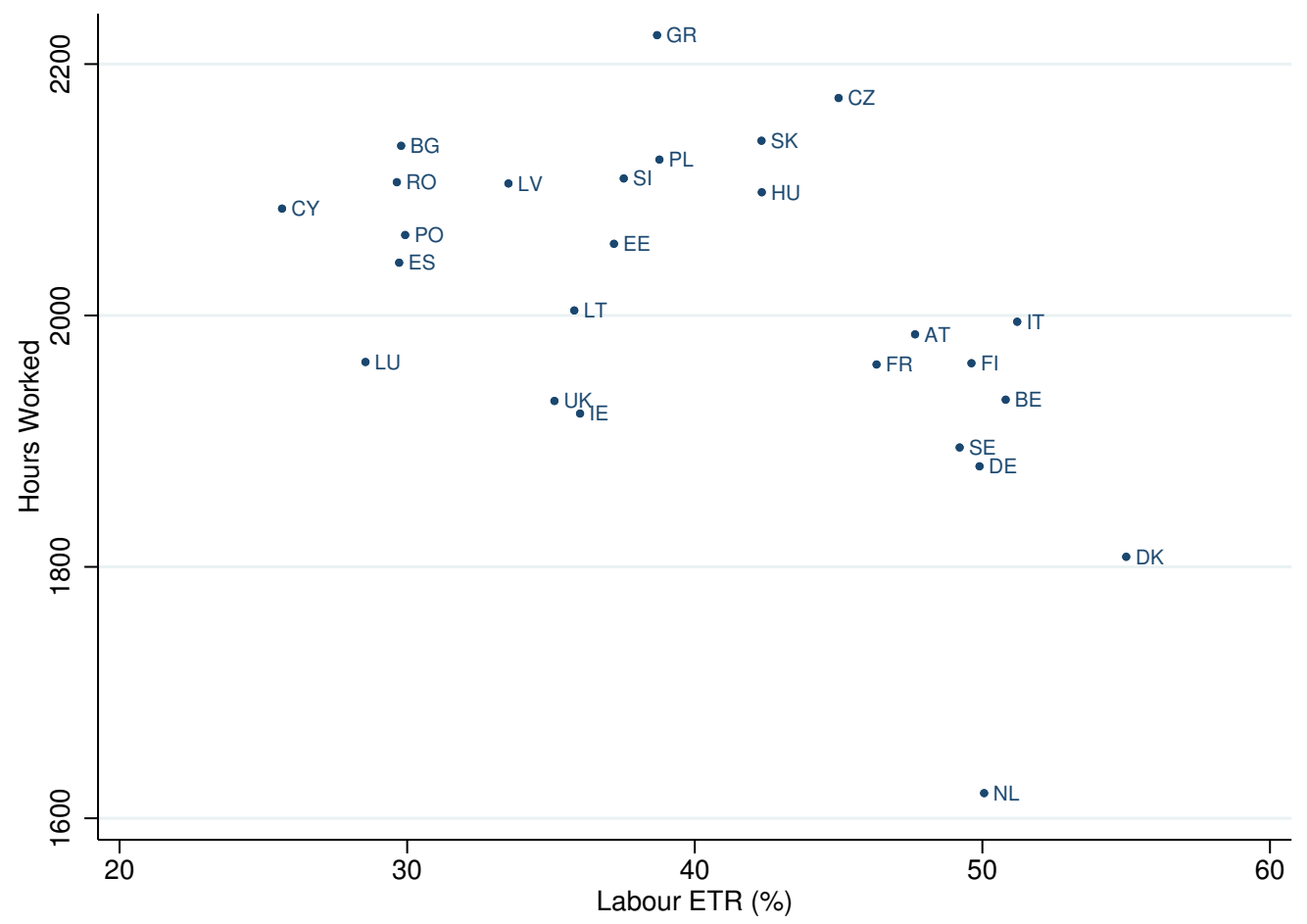

Source: Authors' calculations.

Note: In the y-axis average annual hours worked are defined as the total number of hours worked per year divided by the average number of people in employment per year. 
Figure 9: ETRs and Investment
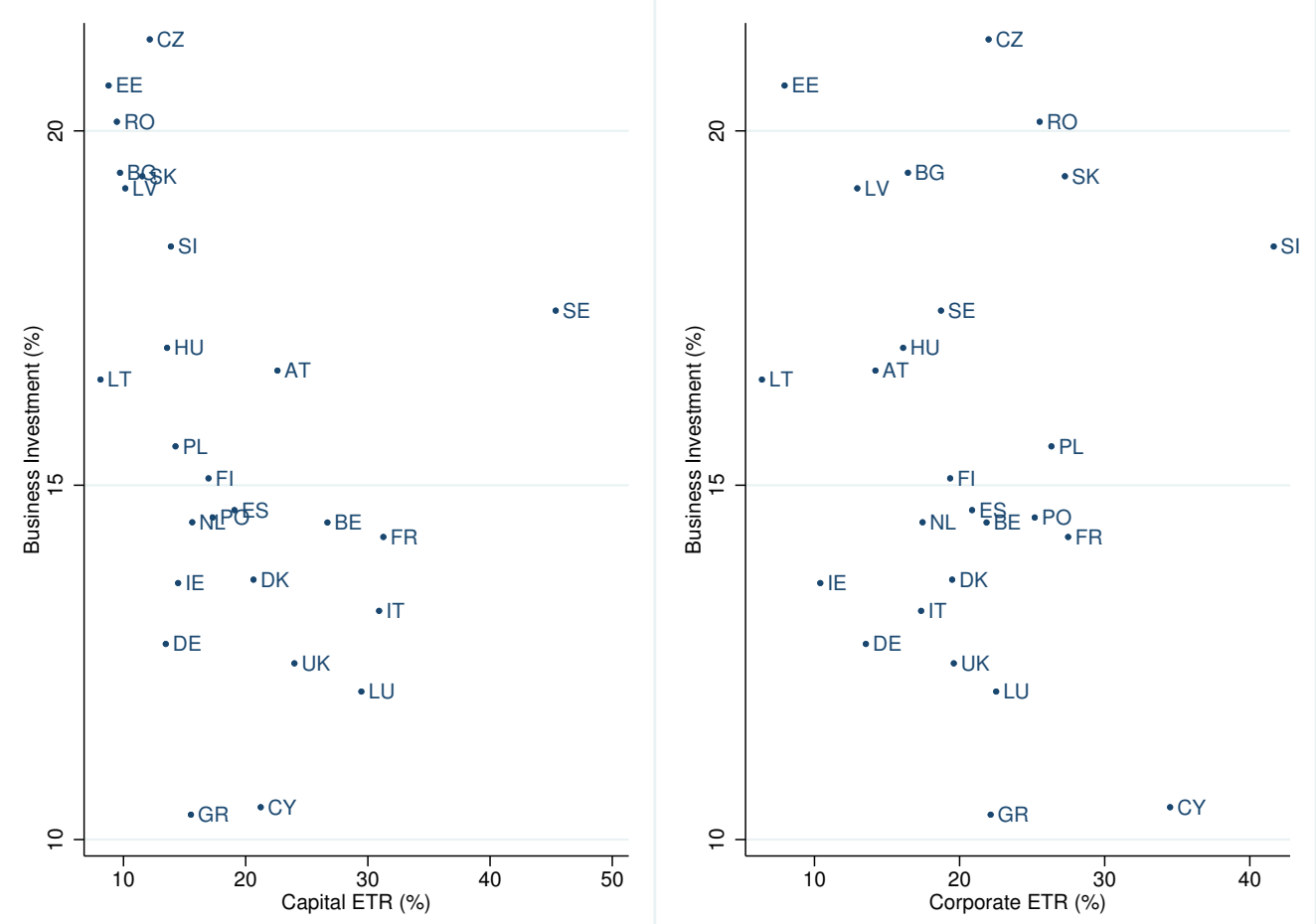

Source: Authors' calculations.

Note: In the y-axis business investment is defined as the Gross Fixed Capital Formation of Households and NPISH, Non-Financial and Financial corporations as a share of GDP in each country. 


\section{Conclusions}

This paper computes estimates of aggregate, ex post, effective tax rates for the Irish economy covering the 1995-2017 period. Following the approach of Mendoza et al. (1994) and Carey and Rabesona (2002), we estimate tax rates for the factors of production, consumption, corporate income and social security contributions.

The ETR indicators illustrate significant differences between the Irish tax structure and that of the EU countries. In Ireland, effective tax rates on labour, capital and corporate income are lower compared to the EU average, while the tax burden on consumption is consistently higher. Relating these estimates to macroeconomic variables of interest we find that, as predicted by the theory, labour taxes are negatively correlated with hours worked, while capital and corporate taxes are negatively related with business investment. This set of results indicates that the policy mix followed by Ireland is positively correlated with GDP growth, and thus could be a contributing factor to the country's strong economic performance.

As our results stem from a descriptive analysis, we stress that despite the presence of strong correlations, they should not be given any causal interpretation. A more detailed study of the tax structure, based on formal econometric models and testing, is left for future research.

\section{References}

Angelopoulos, K., G. Economides and P. Kammas (2007). 'Tax-Spending Policies and Economic Growth: Theoretical Predictions and Evidence from the OECD', European Journal of Political Economy, 23(4):885-902.

Arachi, G., V. Bucci and A. Casarico (2015). 'Tax Structure and Macroeconomic Performance', International Tax and Public Finance, 22(4):635-662.

Berger, T. and G. Everaert (2010). 'Labour Taxes and Unemployment: Evidence from a Panel Unobserved Component Model', Journal of Economic Dynamics and Control, 34(3):354-364.

Carey, D. and J. Rabesona (2002). 'Tax Ratios on Labour and Capital Income and on Consumption', OECD Economic Studies, 35.

Carey, D. and H. Tchilinguirian (2000). 'Average Effective Tax Rates on Capital, Labour and Consumption', OECD Economic Department Working Papers, 258.

Casey, E. and A. Hannon (2016). 'Challenges Forecasting Irish Corporation Tax', Irish Fiscal Advisory Council Analytical Note No. 10.

Coffey, S. (2017), 'Review of Ireland's Corporation Tax Code'.

Coffey, S. and K. Levey (2014). 'Effective Rates of Corporation Tax in Ireland', Department of Finance Technical Paper. 
Daveri, F. and G. Tabellini (2000). 'Unemployment, Growth and Taxation in Industrial Countries', Economic Policy, 15(30):47-104.

Dellas, H., D. Malliaropoulos, D. Papageorgiou and E. Vourvachaki (2017). 'Fiscal Policy with an Informal Sector', Bank of Greece Working Paper Series No. 235.

European Commission (2007-2019). 'Taxation Trends in the European Union Report', Directorate General for Taxation and Customs Union.

Fiorito, R. and F. Padrini (2001). 'Distortionary Taxation and Labour Market Performance', Oxford Bulletin of Economics and Statistics, 63(2):173-196.

Gemmell, N., R. Kneller and I. Sanz (2014). 'The Growth Effects of Tax Rates in the OECD', Canadian Journal of Economics, 47(4):1217-1255.

Irish Fiscal Advisory Council (2018), 'Fiscal Assessment Report'.

Irish Fiscal Advisory Council (2019), 'Fiscal Assessment Report'.

Kneller, R., M. Bleaney and N. Gemmell (1999). 'Fiscal Policy and Growth: Evidence from OECD Countries', Journal of Public Economics, 74:171-190.

Kostarakos, I. and P. Varthalitis (2020). 'Effective Tax Rates in the EU: An Updated Database', mimeo.

Larch, M., J. Malzubris and S. Santacrose (2016). 'Fiscal Consolidation in Ireland: Recent Successes and Remaining Challenges', European Economy Economic Brief 011.

Lee, Y. and R. Gordon (2005). 'Tax Structure and Economic Growth', Journal of Public Economics, 89(5-6):1027-1043.

Martinez-Mongay, C. (2000). 'ECFIN's Effective Tax Rates. Properties and Comparisons with Other Tax Indicators', European Commission, Directorate for Economic and Financial Affairs, Economic Paper No. 146.

McCarthy, J. (2015). 'Fiscal Consolidation and Structural Reforms - the Irish Perspective', Presentation to the German Finance Ministry Conference, Berlin.

McDaniel, C. (2007). 'Average Tax Rates on Consumption, Investment, Labor and Capital in the OECD 1950-2003', Working Paper.

McQuinn, K. and P. Varthalitis (2020). 'How Openness to Trade Rescued the Irish Economy', in N. Campos, P. De Grauwe, and Y. Ji (Eds.), Economic Growth and Structural Reforms in Europe, Cambridge: Cambridge University Press:377-406. 
Mendoza, E., A. Razin and L. Tesar (1994). 'Effective Tax Rates in Macroeconomics: Cross-Country Estimates of Tax Rates on Factor Incomes and Consumption', Journal of Monetary Economics, 34(3): 297-323.

Mendoza, E., G. Milesi-Ferretti and P. Asea (1997). 'On the Ineffectiveness of Tax Policy in Altering Long-Run Growth: Harberger's Superneutrality Hypothesis', Journal of Public Economics, 66:99-126.

Papageorgiou, D., T. Efthimiadis and I. Konstantakopoulou (2012). 'Effective Tax Rates in Greece', Centre for Planning and Economic Research Discussion Papers, Discussion Papers no. 124.

Revenue Commissioners (2020), 'Corporation Tax 2019 Payments and 2018 Returns'.

Uhlig, H. and M. Trabandt (2011). 'The Laffer Curve Revisited', Journal of Monetary Economics, 58(4): 305-327.

Volkerink, B., J. Sturm and J. de Haan (2002). 'Tax Ratios in Macroeconomics: Do Taxes Really Matter', Empirica, 29(3):209-224. 


\section{A Appendix}

\section{A.1 Formulas}

In this Appendix we present the formulas used for the computation of the effective tax rates. For a detailed presentation of the model and the derivations we refer to the technical paper by Kostarakos and Varthalitis (2020). The effective tax rate on consumption is computed as follows:

$$
\tau^{c}=\frac{D 2-D 214 C-D 51 D-D 29}{P 3+P 2}
$$

A well-documented problem related to the computation of effective tax rates on labour and capital income is that tax revenue sources do not provide a breakdown of personal income tax into its labour and capital components. To address this issue, we follow Mendoza et al. (1994) and assume that both the labour and capital income of households are taxed at the same rate, $\tau^{h}$. The effective tax rate on household income is given by:

$$
\tau^{h}=\frac{D 51 A C 1}{(D 1-D 611-D 613)+\left(B A 43 G^{h h}-P 51 C^{h h}\right)+\left(D 41 r^{h h}-D 41 p^{h h}\right)}
$$

Then, the effective tax rate on labour income is given by:

$$
\tau^{l}=\frac{\tau^{h}(D 1-D 611-D 613)+D 611+D 613}{D 1}
$$

The effective tax rate on capital income is given by:

$$
\tau^{k}=\frac{\left(\tau^{h} * H C I\right)+C A P T}{B 2 A 3 G^{\text {total }}-P 51 C^{\text {total }}}
$$

where $H C I=\left(B 2 A 3 G^{h h}-P 51 C^{h h}\right)+\left(D 41 r^{h h}-D 41 p^{h h}\right)$

and CAPT is defined as the sum of taxes on the income or profits of corporations, D51B_C, taxes on financial and capital transactions, D214C, capital taxes, D91, current taxes on capital, D59A, taxes on winnings from lottery and games, D51D, stamp taxes, D214B, and other taxes on production, D29+D29H - see Dellas et al. (2017). The effective tax rate on corporate income is given by:

$$
\tau^{c o r p}=\frac{D 51^{f c}+D 51^{n f c}}{\left(B 2 A 3 G^{f c}+B 2 A 3 G^{n f c}\right)-\left(P 51 C^{f c}+P 51 C^{n f c}\right)}
$$


It is straightforward to decompose the overall corporate income tax rate into the tax rate for non-financial and financial corporations, $\tau^{\operatorname{corpnf} c}$ and $\tau^{\operatorname{corpfc}}$, respectively:

$$
\begin{aligned}
\tau^{\text {corpnfc }} & =\frac{D 51^{n f c}}{B 2 A 3 G^{n f c}-P 51 C^{n f c}} \\
t^{\text {corpfc }} & =\frac{D 51^{f c}}{B 2 A 3 G^{f c}-P 51 C^{f c}}
\end{aligned}
$$

Finally, the effective tax rate on social security contributions is given by

$$
\tau^{s s c}=\frac{D 611+D 613}{D 1}
$$

Again, it is straightforward to decompose the overall $\tau^{s s c}$ into the tax rates for households and employers:

$$
\begin{aligned}
\tau^{s s c^{h}} & =\frac{D 613}{D 1} \\
\tau^{s s c^{e m p}} & =\frac{D 611}{D 1}
\end{aligned}
$$

Finally, the combined labour and consumption effective tax rate is given by:

$$
\tau^{l c}=\tau^{l}+\left(1-\tau^{l}\right) * \tau^{c}
$$




\section{A.2 Data}

Table A1: Data

\begin{tabular}{|c|c|}
\hline \multicolumn{2}{|r|}{ Tax Revenue Data } \\
\hline $\begin{array}{l}\text { ESA } 2010 \text { Code } \\
\text { D2 } \\
\text { D214B } \\
\text { D214C } \\
\text { D29 } \\
\text { D29H } \\
\text { D59A } \\
\text { D51 } \\
\text { D51 } 1^{f c} \\
\text { D51A_C1 } \\
\text { D51B_C2 } \\
\text { D51D } \\
\text { D91 }\end{array}$ & $\begin{array}{c}\text { Definition } \\
\text { Taxes on production and imports } \\
\text { Stamp taxes } \\
\text { Taxes on financial and capital transactions } \\
\text { Other taxes on production } \\
\text { Other taxes on products n.e.c. } \\
\text { Current taxes on capital } \\
\text { Taxes on income paid by non-financial corporations } \\
\text { Taxes on the income and profits of corporations including holding gains } \\
\text { Taxes on individual or household income including holding gains } \\
\text { Taxes on income paid by financial corporations } \\
\text { Taxes on winnings from lottery or gambling } \\
\text { Capital taxes }\end{array}$ \\
\hline \multicolumn{2}{|r|}{ National Accounts Data } \\
\hline ESA 2010 Code & Definition \\
\hline $\begin{array}{l}\mathrm{B} 2 \mathrm{~A} 3 \mathrm{G}^{h h} \\
\mathrm{~B} 2 \mathrm{~A} 3 \mathrm{G}^{n f c} \\
\mathrm{~B} 243 \mathrm{G}^{f c} \\
\mathrm{~B} 2 \mathrm{~A} 3 \mathrm{G}^{\text {total }} \\
\text { D1 } \\
\mathrm{D} 41 \mathrm{P}^{h h} \\
\mathrm{D} 41 \mathrm{R}^{h h} \\
\mathrm{D} 611 \\
\mathrm{D} 613 \\
\text { P2 } \\
\text { P3 } \\
\text { P51Ch } \\
\text { P51C } \\
\text { P51C }^{\text {fc }} \\
\text { P51C }\end{array}$ & $\begin{array}{c}\text { Gross Operating Surplus and mixed income of households } \\
\text { Gross Operating Surplus and Mixed Income, non-financial corporations } \\
\text { Gross Operating Surplus and Mixed Income, financial corporations } \\
\text { Gross Operating Surplus and Mixed Income, total economy } \\
\text { Compensation of Employees } \\
\text { Interest Income Paid, households } \\
\text { Interest Income Received, households } \\
\text { Employers actual Social Security Contributions } \\
\text { Households actual Social Security Contributions } \\
\text { Intermediate Consumption, government } \\
\text { Households and NPISH final consumption expenditure } \\
\text { Consumption of Fixed Capital, households } \\
\text { Consumption of Fixed Capital, non-financial corporations } \\
\text { Consumption of Fixed Capital, financial corporations } \\
\text { Consumption of Fixed Capital, total economy }\end{array}$ \\
\hline
\end{tabular}


Whitaker Square,

Sir John Rogerson's Quay,

Dublin 2

Telephone +35318632000

Email admin@esri.ie

Web www.esri.ie

Twitter @ESRIDublin

ISBN 978-0-7070-0543-0 